\title{
Hyperinsulinaemic hypoglycaemia due to chlorpropamide-induced nesidioblastosis
}

\author{
G RAYMAN, ${ }^{*}$ M SANTO,$\dagger$ F SALOMON,$\dagger S$ ALMOG,$\dagger$ FJ PARADINAS,$\ddagger \mathrm{J}$ PINKHAS, $\dagger$ \\ KW REYNOLDS,§ PH WISE* \\ From the $†$ Departments of Medicine and Toxicology Unit, Sackler Faculty of Medicine, Tel-Aviv University, \\ Israel, and the Departments of $\ddagger$ Pathology, §Surgery, and ${ }^{*}$ Endocrinology, Charing Cross Hospital, London
}

SUMMARY A 25 year old woman suffering from recurrent attacks of hypoglycaemia underwent a laparotomy for suspected insulinoma. No tumour was found, but histology showed islet cell hyperplasia and nesidioblastosis. Although these changes have been reported as a cause of hypoglycaemia in infants, they are only rarely the cause of hypoglycaemia in adults; in the present case they were found to be the result of covert sulphonylurea administration. The fact that sulphonylureas can cause nesidioblastosis is not well recognised by either physicians or pathologists and it should be considered before "cryptogenic nesidioblastosis" is deemed the cause of hypoglycaemia in adults.

In adults, hyperinsulinaemic hypoglycaemia is usually associated with an islet cell adenoma or carcinoma. ${ }^{12}$ Nesidioblastosis, a term used by Laidlaw ${ }^{3}$ to describe the neoformation of islet cells from pancreatic duct epithelium, is often found in association with other islet cell abnormalities, such as hyperplasia and adenomatosis, as a cause of inappropriate insulin secretion in infants; ${ }^{45}$ but only rarely has it been reported in adults. ${ }^{67}$ We describe a case in which adult nesidioblastosis was associated with factitious hypoglycaemia produced by sulphonylurea.

\section{Case report}

A 25 year old divorced mother of two presented to the Department of Medicine, Sackler Faculty of Medicine, with a two week history of recurrent attacks of fainting, profuse sweating, and hunger. She had a history of gestational diabetes requiring insulin in her first pregnancy which, unusually, did not recur in her second pregnancy. The patient denied abusing alcohol or taking any drugs. Physical examination was normal except for burn scars sustained during childhood. Hypoglycaemia was suspected clinically and confirmed on several occasions when the plasma glucose concentration fell below $2.2 \mathrm{mmol} / \mathrm{l}$. Additional findings of inappropriately high plasma insulin concentration $(38.5 \mathrm{mU} / \mathrm{l})$ during hypoglycaemia $(1.5 \mathrm{mmol} / \mathrm{l})$ supported the diagnosis of an insulin secreting tumour.

Accepted for publication 13 February 1984
The possibility of factitious hypoglycaemia was considered, but a thorough search of her room and constant surveillance revealed no evidence of drug intake. Self administration of insulin was excluded by the later finding of normal unsuppressed $C$ peptide concentrations $(0.5 \mathrm{pmol} / \mathrm{ml})$ during hypoglycaemia, thus strengthening the possibility of an islet cell tumour. Abdominal ultrasound examination showed slight enlargement of the tail of the pancreas, but no localised tumour was seen. Selective angiography of the superior mesenteric and splenic arteries revealed no abnormality.

Initially, she was treated with constant infusion of $10 \%$ dextrose solution and boluses of $50 \%$ dextrose during hypoglycaemic episodes; later she was given $400 \mathrm{mg} /$ day of diazoxide and $325 \mathrm{mg} /$ day of propranolol, but severe hypoglycaemic episodes continued. Accordingly, she was referred to Charing Cross Hospital, London, so that transhepatic catheterisation of pancreatic veins and insulin assay could be considered for preoperative localisation of a presumptive tumour. Repeat ultrasound examination and computed tomography of the abdomen confirmed slight enlargement of the tail of the pancreas but no tumour was identified. At laparotomy no tumour could be located, and a subtotal $(75 \%)$ distal pancreatectomy was performed. Following this, blood glucose concentration rose to $22 \mathrm{mmol} / 1$ within one hour. The postoperative period was complicated by an episode of unexplained supraventricular tachycardia and hypotension, but blood glucose concentrations remained in the normal range. 


\section{MATERIAL AND METHODS}

The pancreatic tissue removed was in five fragments, with a total weight of $58 \mathrm{~g}$. It was sliced at $3 \mathrm{~mm}$ intervals and fixed in neutral formalin. One millimetre cubes were postfixed in $1 \%$ osmium tetroxide, block stained in $2 \%$ aqueous uranyl acetate, and processed to Araldite resin. Gold interference colour ultrathin sections were stained with Reynold's lead citrate and examined with a Philips electron microscope. The rest of the tissue was embedded in paraffin and $3 \mu \mathrm{m}$ sections stained with haematoxylin and eosin, Gomori's aldehyde fuschin, and Grimelius silver impregnation for argyrophilia. Immunohistochemical stains for insulin, glucagon, gastrin, pancreatic polypeptide, and secretin were also carried out (Dr J Polak) in paraffin embedded tissue by an immunoperoxidase method. The estimation of the endocrine cell mass was performed in random sections by a point counting method. ${ }^{8}$

\section{RESULTS}

No neoplasm was seen with the naked eye or on histological examination of all the tissue received. Assessment of the pancreatic islet cell mass showed an insular mass of $4.6 \%$ of the total pancreas, equivalent to about 2.4 times the normal range $(0.55$ 2.9; mean 1.97). ${ }^{8}$ This was due to an increase in the size and number of islets, some of which were small and appeared to be budding from large islets or ducts (Fig. 1). There were also endocrine cells in the walls of large ducts (Fig. 2) as well as endocrine cells forming small tubules and clusters among exocrine cells (Fig. 3). Electron microscopy showed isolated endocrine cells among exocrine cells (Fig. 4). Both insulin type granules, characterised by rectangular

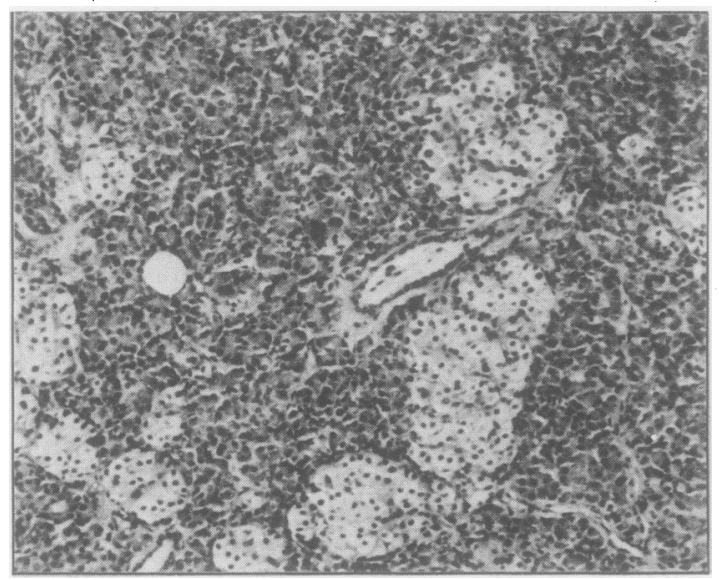

Fig. 1 Small, irregularly shaped islets adjacent to a duct (middle of the picture) and small groups of endocrine cells among exocrine tissue. Haematoxylin and eosin. Original magnification $\times 100$.

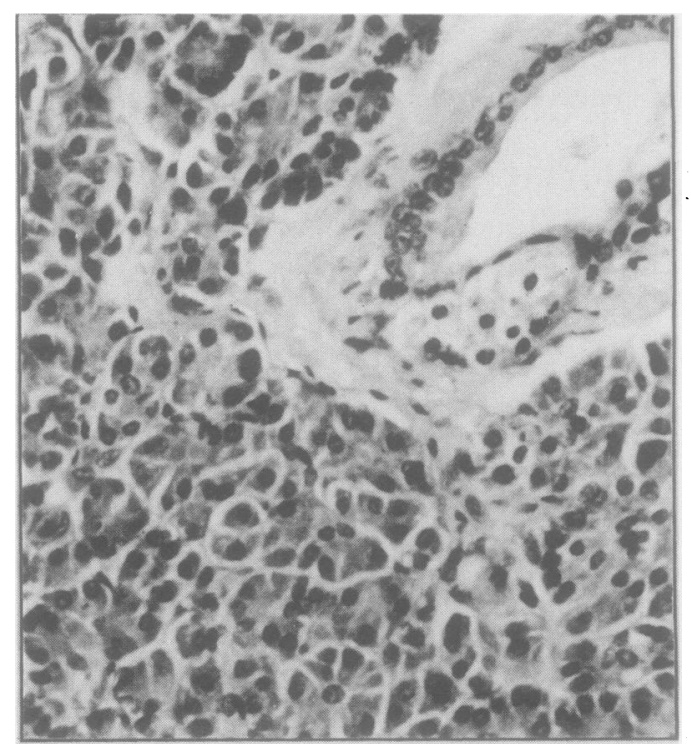

Fig. 2 Group of endocrine cells in the wall of a duct (nesidioblastosis). This appearance is not seen in the normato adult pancreas. Haematoxylin and eosin. Original magnification $\times 250$.

-structures within dense core granules (Fig. 5), ands glucagon type granules, characterised by $250 \mathrm{~nm} \overline{\mathrm{O}}$ average size and thin attenuated halos,". were seen⿳亠丷厂 outside islets. Most cells positive with aldehyde fus- $\mathbb{\perp}$ chin $(\beta$ cells) showed partial degranulation.

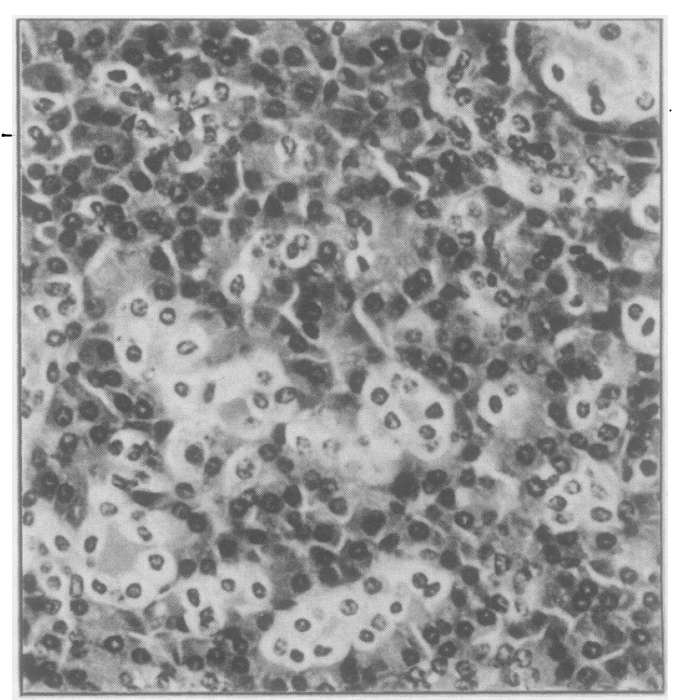

Fig. 3 Groups of endocrine cells forming clusters and tubules among exocrine tissue. This tubular proliferation endocrine cells is a feature in the pancreas after sulphonylurea administration. Haematoxylin and eosin. Original magnification $\times 250$. 


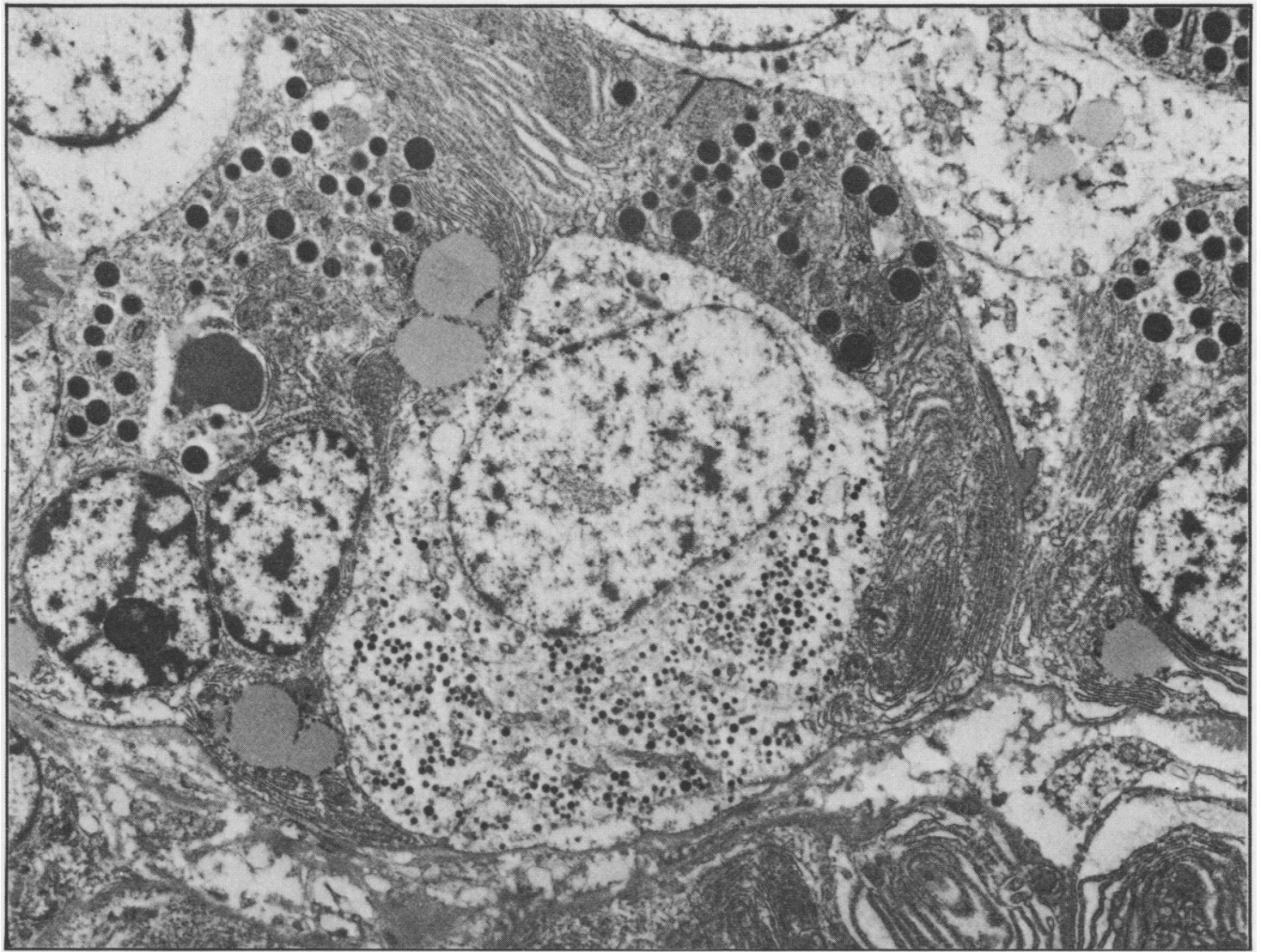

Fig. 4 Endocrine cell containing non- $\beta$ dense core granules surrounded by exocrine cells with prominent endoplasmic reticulum and large zymogen granules. There is no basal lamina separating endocrine and exocrine cells. Original magnification $\times 7480$.

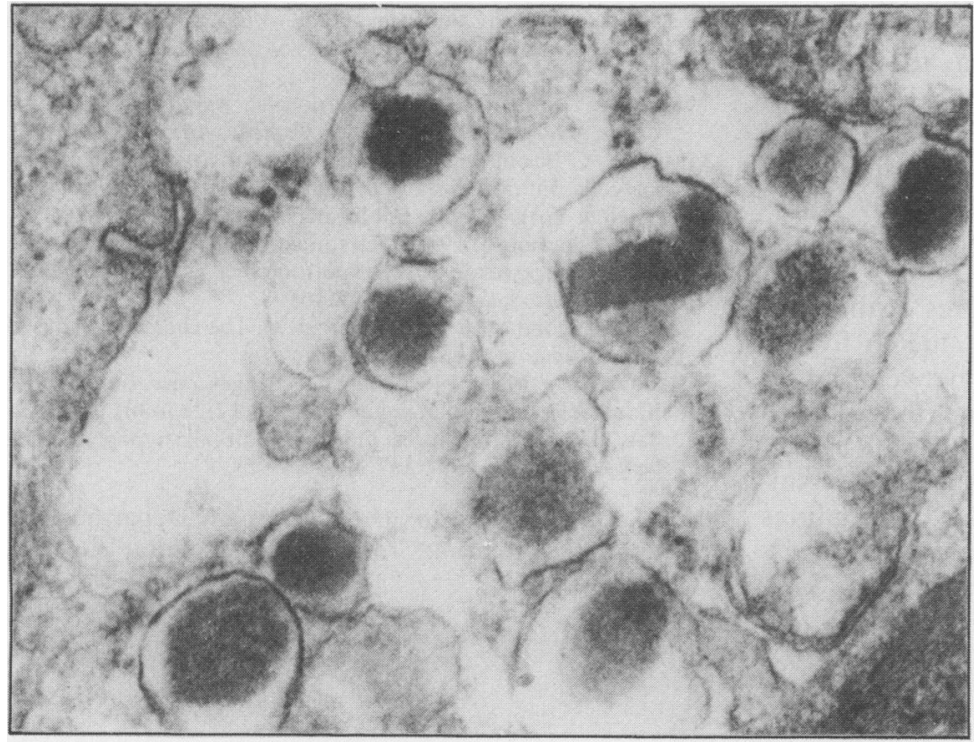

Fig. 5 Dense core granules, some with rectangular crystalline structure characteristic of insulin. From cell found among exocrine acinar tissue. Original magnification $\times 64660$. 
Grimelius positive cells were seen both within and outside islets. Immunoperoxidase showed an increase in endocrine cells of all types without alteration of their relative proportions. Islet cell hyperplasia with nesidioblastosis was therefore diagnosed.

\section{FOLLOW UP}

Three weeks after operation the patient returned to Israel and was readmitted to the department with severe hypoglycaemia. The question of self induced hypoglycaemia was raised again and on this occasion blood samples were tested for hypoglycaemic agents using a high performance liquid chromatography technique.$^{10}$ High concentrations of chlorpropamide were found in both present and preoperative samples. Further light was cast on the problem when the staff of the toxicology laboratory recognised this patient as the mother of an 18 month child whom she had repeatedly poisoned in the past with chlorpromazine (the case history has been published in detail elsewhere $\left.{ }^{\prime \prime}\right)$. When confronted with the facts the patient vehemently denied taking chlorpropamide or any other drug; nevertheless, after this confrontation her hypoglycaemic episodes did not recur.

\section{Discussion}

Neoformation of islets from pancreatic ducts occurs during fetal life and to some extent during the first and possibly second year of life. ${ }^{5}$ An exaggeration of this process, associated with islet cell hyperplasia or neoplasia, has been reported as a cause of hypoglycaemia in infancy. ${ }^{45}$ Sulphonylurea treatment both in man and animals has been reported to produce similar changes in the pancreas. ${ }^{12}$ It therefore seems likely that chlorpropamide was the cause of the histological changes in this case. There have been previous reports of adult nesidioblastosis with hypersecretion of insulin, ${ }^{67}$ but, although the possibility of sulphonylurea administration was considered in some of them, ${ }^{6}$ this was never excluded by examination of the plasma.

The clinical and biochemical features of this case are characteristic of hypoglycaemia due to hypersecretion of insulin. The distinction between hypoglycaemia due to an insulinoma and that due to abuse of sulphonylurea drugs is not possible, however, without serum determination of sulphonylureas, since the biochemical abnormalities are similar. This case therefore supports the suggestion made by Jordan that all patients with profound hypoglycaemia without demonstrable evidence of an islet cell tumour should have their blood assayed for sulphonylureas before laparotomy.

This patient can be classified as a typical malingerer (Munchausen syndrome), who used chlorpropamide to produce factitious disease. Her problem is intriguing in that she had previously abused her child by using a drug overdose, a condition known as Polle's syndrome. The finding of nesidioblastosis in adults should therefore alert the physician and the pathologist to the possibility of a drug induced cause.

We thank Dr A Weinberger, Dr I Sidi, Dr $M$ Gapany, Dr J Polak, Professor Z Laron, and Professor ED Williams for their help in evaluating this case.

\section{References}

I Mengoli L, LeQuesne L. Blind pancreas resection for suspected insulinoma: a review of the problem. Br J Surg 1967;54:74956.

2 Service FJ, Dale AJD, Elveback LR, Jiang NS. Insulinoma: Clin- $\overrightarrow{0}$ ical and diagnostic features of 60 consecutive cases. Mayo Clin Proc 1976;51:417-29.

${ }^{3}$ Laidlaw GF. Nesidioblastoma: the islet cell tumour of the pancreas. Am J Pathol 1938;14:125-34.

4 Yakovac WC, Baker L, Hummeler K. Beta cell nesidioblastosis in idiopathic hypoglycaemia of infancy. $J$ Pediatr 1971;79:226-31.

${ }^{5}$ Dahms BB, Landing BH, Blaskovics M, Roe TF. Nesidioblastosis and other islet cell abnormalities in hyperinsulinaemic hypoglycaemia of childhood. Hum Pathol 1980; 6:641-9.

- Nathan DM, Axelrod L, Proppe KH, Wald R, Hirsch HJ, Martin DB. Nesidioblastosis associated with insulin mediated hypoglycaemia in an adult. Diabetes Care 1981;4:383-8.

7 Weidenheim KM, Hinchey WW, Campbell WG. Hyperinsulinemic hypoglycaemia in adults with islet-cell hyperplasia and degranulation of exocrine cells of the pancreas. Am J Clin Pathol 1983;79:14-24.

${ }^{8}$ Gepts W. Le pancréas endocrine normal. Annales de la Societé Royale Medecine et Naturelle de Bruxelles 1957;10:14-50.

' Dayal Y, O'Briain DS. The pathology of the pancreatic endocrine cells. In: de Lelis R, ed. Diagnostic immunohistochemistry. New York: Masson Publishing USA Inc, 1981:123.

${ }^{10}$ Hill RE, Crecaiolo J. 1978. Determination of serum tolbutamide $\frac{D}{O}$ and chlorpropamide by high-performance liquid chromatography. J Chromatogr 1978;145:165-8.

"Shnaps Y, Frand M, Rotem Y, Tirosh M. The chemically abused $G$ child. Paediatrics 1981;68:119-21.

12 Bloodworth JMB. Morphologic changes associated with sufonylurea therapy. Metabolism 1963;12:287-301.

13 Jordan RM. Sulphonylurea induced factitious hypoglycaemia. Arch Intern Med 1977;137:390-3

Requests for reprints to: Dr G Rayman, Department of Endocrinology, Charing Cross Hospital, London W6 8RF, England. 